BRSS VOL 1 NO 2 ISSN: 2687-2293

Available online at www.bussecon.com

\title{
Integrated technologies, advances and benefits in Industry 4.0
}

\author{
Selman Duran ${ }^{a *}$, Gülgün Şengil ${ }^{b}$ \\ ${ }^{a}$ Ph.D., School of Business, Istanbul Medipol University, Beykoz, 34500, Istanbul, Turkey. \\ ${ }^{a}$ Institute of Social Science, Istanbul Medipol University, Beykoz, 34500, Istanbul, Turkey
}

Crossref

\begin{tabular}{l} 
A R T I C L E I N F O \\
\hline Article history: \\
Received 10 April19 \\
Received in revised form 22 Sept 19 \\
Accepted 07 October19 \\
\hline Keywords: \\
Industry 4.0 \\
Digital Business \\
IoT \\
Digitalization \\
JEL Classification: \\
A11, D43
\end{tabular}

\begin{abstract}
A B S T R A C T
Expressing the digitalization of industry in today's world which is rapidly developing day by day, Industry 4.0 is accepted as the most important technology revolution of our time. This shows that a new era in production has started and the industry has been digitized. In order to adapt to this change, companies should actively follow the innovations and shape the organizational structure accordingly. However, if this is the case, we can respond to the expectations of the current period. That is why it is necessary to activate Industry 4.0 after learning all aspects of it and to develop marketing strategies that can adapt to this digital age. In today's competitive environment, it is inevitable to act integrated into this new situation. This study is designed to emphasize how important it is to identify Industry 4.0 and the most heavily affected marketing strategies from it. It is also a review of the conceptual explanation of Industry 4.0 and the importance of advances in new technologies .
\end{abstract}

(C) 2019 Bussecon International Academy. Hosting by Bussecon International. All rights reserved. Peer review under responsibility of Bussecon International Academy.

\section{Introduction}

Society surrounding us is changing each day. There are also fundamental changes in industry. One of them is the industrial revolution. The last actor of this revolution is the fourth industrial revolution, also known as Industry 4.0. This concept aims to enable all units to communicate with each other in order to achieve the highest benefit in the production process, to reach the planned data at the desired time and in this way to achieve the outputs that will meet the expectations at the best level (Soylu, 2018). In our era, early industrialized countries shape their industrial forces with Industry 4.0, the fourth stage of industrialization. This new process involves a structure that changes production and consumption completely. Industry 4.0 represents a new era of production systems that adapt to the rapidly changing demands of the consumer on the one hand, and on the other hand, a new era of integrated automation systems that constantly communicate with each other (Alçın, 2016).

The development of the world in the digital sense plays a key role in the appearance of the concept of Industry 4.0. The internet of objects caused by this development, smart factories, cyber-physical systems and devices that can communicate with each other are very important factors (Soylu, 2018). Digital transformation has given us two concepts. The first one is the conversion of printed or physical form materials (text, pictures, sound, etc.) to digital form by computer. The second is the transformation of strategies and business models beyond the transformation of materials into digital forms (Aybek, 2017:67).

It is usual to see the production-based effects of industrial revolutions in Industry 4.0. However, the impacts will not be so limited. Digitalization and automation systems will make you feel strongly in all areas of business. One of the most important factors directly affected by these developments is how the direction of the marketing process will be affected (Soylu, 2018). In this study, Industry 4.0, the latest industrial revolution, is defined and approaches of different perspectives on this issue are explained. On the other hand,

* Corresponding author. Tel.: +90-216-681-51-00; fax: +90-216-531-07555. ORCID ID:0000-0002-2157-5706

Peer review under responsibility of Bussecon International Academy.

(C) 2019 Bussecon International. Hosting by Bussecon International. All rights reserved.

http://dx.doi.org/10.36096/ijbes.v1i2.100 
a comprehensive literature review is made about how this new production paradigm shapes marketing strategies and a review is made in the light of the data obtained.

\section{Literature Review}

In the world, the way things work and how they are done is changing rapidly. The machines that use manpower with steam, which started industrial revolutions, turned into mass production lines with electricity towards the end of the 19th century. In this way, production is increased in a short time. Afterwards, the third Industrial Revolution, which can be called as a turning point in the history of humanity, started with electronic automation. With this transfer, sensor technologies were provided in the factories. Today, however, the industry has taken a new dimension with the Digitalizing Industry period called Industry 4.0. Now, with Industry 4.0, 'the transition to internet' Internet of Things' journey, where everything can be interconnected, has taken place. There is a constant change in this journey (https://ceylanparlakay.com/2017/03/27/pazarlama-ve-reklam-dunyasinda-endustri-4-0-bizi-nasil-etkiliyor/).

Industry 4.0 or the fourth industrial revolution represents a revolution that creates added value by automating processes requiring labor (Sener, Elevli, 2017). What drives Industry 4.0 is the technological change that allows employees in small workshops to find machines that can produce faster and more efficiently (Frederick, 2016: 9). Industry 4.0 was first introduced at Hannover. In this fair, a group of representatives from different fields introduced the new era in order to increase German competitiveness. Now the German government has set up the High Technology Strategy for 2020 and then established a Working Group to be more productive and productive in the implementation of Industry 4.0. This group developed and published their first proposals in 2003. These recommendations consist of Cyber Physical Systems, Intelligent Machines, Storage Systems and production facilities that can autonomously exchange information, trigger actions and control each other independently (Ertuğrul \& Deniz, 2018).

Thanks to Industry 4.0, there has been a rapid transformation in manufacturing and related industries. This transformation is due to ever-increasing customer demand and the necessity of keeping businesses competitive by meeting these demands. Individualized products, Cyber-physical systems (CPS), Internet of Things (IoT), cloud computing and cognitive computing are some of the key factors in this transformation, the so-called Fourth Industrial Revolution or Industry 4.0. In 2011, the German strategic initiative 'Industrie 4.0' made Germany a leader in advanced production solutions. In Industry 4.0, systems have been created to support the transition to intelligent production so that they can exchange information independently and manage the industrial production process.(https://www.optessa.com/blog/industry-4-0-history-technology-business transformation/) Organizations and intelligent robots that want to be ahead of the World competition have to establish an expert team of employees who can integrate the artificial intelligence and internet objects in the $\mathrm{R} \& \mathrm{D}$ processes in a compatible way. (Https://www.fortuneturkey.com/akilli-uretim-cagiendustri-40-42841). The latest studies are illustrated in a literature table as in appendix.

Scientists who work for businesses that want to be perfect in production have emphasized the importance of focusing on philosophies about ways to improve, thereby arguing that they may be the best in their fields (Gilgeous and Gilgeous, 1999, p. 33). In this way, together with the new technologies used to achieve better, it creates a production structure that is faster, with lower error rate, quality and minimized costs. With digitalization, businesses have started to offer products and services with technologies that enable them to meet the ever-changing demands of customers (Buhr, 2017: 5). In order to give the necessary importance to the production generated by utilizing these technologies, it will be effective to make use of big data in the discovery of new markets by making accurate predictions about the expectations of consumers by considering the previous purchasing behaviors. In this way, it will be possible to produce information simultaneously (Ovac1, 2017: 128).

In order to support the production of personalized products that these technologies allow, it will be useful to make use of big data in estimating consumer preferences and evaluating new market opportunities based on previous purchasing behaviors. Therefore, it will be ensured that ideas based on information are obtained at the same time in innovation periods (Ovac1, 2017: 128). The European Union, which stands behind the digital transformation of industry, has many national initiatives. The European Commission is developing the most appropriate strategy to support these initiatives.

The European industry digitalization plan focused on facilitating the system enabling industrial companies to access digital technologies (ii) building the digital industry infrastructure of Europe, keeping the necessary labor force ready to take advantage of digital transformation, and providing appropriate solutions for the expansion of digital transformation.

\section{Industry 4.0, integrated technologies and benefits}

Nowadays, businesses are trying to survive under increasing competition conditions. In this process of information age, human has increased its value day by day. By replacing the material resources in the center of the enterprise with information, many concepts have emerged which can provide competitive advantage and one of these concepts, intellectual capital, has added value to its value. In addition, considering that people will dominate the financial resources of the enterprise, it should be understood that the value of employees with knowledge must be above all other. Forethought and generating new ideas has gained importance in this age in which technology is advancing rapidly, the demands of the customers differentiate day by day, the ideas included in the future are constantly renewed and even the expectations between yesterday and tomorrow are not the same. Generating new ideas is not a value that a machine can do. Therefore, knowledge and people are needed to generate new ideas. Businesses should find ways to access information and make it a goal of the business to use it to generate new ideas where necessary. Businesses that achieve this condition 
will make themselves different from other businesses, will become a forward-looking enterprise and will make themselves superior in the competition( Hacioglu and Sevgilioglu, 2019; Hacioglu, 2019; Hacioglu, 2020a; Hacioglu, 2020b). At the same time, the enterprise will increase productivity through the products or services of which outputs it will take by using the intellectual capital while producing a product or service and, by providing less output and more output, will reduce business costs and increase profits. Intellectual capital, according to Itami (1987), has been defined as an invisible important asset which is gaining importance increasingly in the globalizing world and which provides competitive advantage. (Özevren, Y1ldiz 2010 ). According to Stewart (1997), intellectual capital is packaged useful information. Stewart emphasized that intellectual capital is the sum of everything that is known and adopted by all employees of the enterprise or that will provide competitive advantage (Y1ld1z, 2010; Stewart, 1997). Knowing and managing the correct definition of intellectual capital is important for the businesses. In the early 2000s, the importance of intellectual capital has begun to be understood globally. Studies have been made to measure, report and manage intellectual capital in many parts of the world, and these studies still continue. (Özevren, Star 2010). The term of intellectual capital is defined by the Organization for Economic Development and Cooperation (OECD) as the economic value of the intangible assets owned by enterprises, more clearly of the organizational capital and human capital (Karacan 2004; Nerdrum 2001). Intellectual capital has become more important in today's world by giving up the idea that a company is just a tangible and perceptible asset with the definitions of intellectual capital. It is concluded that intangible resources should be considered as important as the tangible assets within the company.

\section{Cyber-Physical Systems}

In the clearest sense, the increase in automation in production, the transition to fully automation and then sensor, stimulator, etc. cyber-physical systems are called integrated systems that will work with robots taking the place of employees who do simple and repetitive works with the developments like human power. 2 --- objects-internet - cyber-physical-system are - smart-factories / blog $/$ ? blogno = 541 046). Cyber Physical Systems (SFS) is a feedback control system that is the output of a wide range of digital sensing. In this case, the devices access the information from the control system and in the light of this information, they perform continuous control cycles in the system. Cyber-physical systems are the integration of the processing processes of the production line, the calculation and the network, where the embedded calculations continuously monitor and control the production processes, as well as feedback loops through which the production process can affect the calculations. In this context, Industry 4.0 makes use of the technologies required to make decisions in production systems or to make a synthesis of physical and digital technologies in the whole production system (Toker, 2018).

Internet of Things

The Internet of Things is an event based on the connection of objects to the Internet. It is a paradigm that enables objects to communicate with each other and integrate with each other without human intervention. In the researches, it is expected that approximately 26 billion objects will be interconnected and work within the next few years. The main objective in the Internet of Things is to increase the revenue and the cost of the organization and increase the efficiency of the outputs. (Toker, 2018). The Internet of Things is defined as a worldwide network of objects among themselves and the communication of objects in a particular contract with each other. It is also possible to define it roughly as a system of devices that have formed an intelligent network by communicating with each other and connecting and sharing information thanks to various communication protocols (Özsoylu, 2017).

The camera system, which was established in 1991 by approximately 15 academicians at the University of Cambridge in order to see the coffee machine, was a horizon application when evaluated under the conditions of that day. The system, which was used until 2001, sent the image of the coffee machine to computer screens three times per minute. Due to the fact that it is online and in real time, it has taken its place in history as the first example of the concept of Internet of Things. In 1999, Kevin Ashton outlined the benefits of RFID technology for P\&G and suggested its use. The proposed system was a global system standard based on radio waves and sensors that created the concept of Internet of Things.

When the Internet of things is mentioned, it is wrong to understand that it is only the connection of devices to the Internet. It is within this concept that RFID-like sensors and identifiers generate information with certain devices. When equipped with objects, sensors and electronic circuits, they acquire the ability to update status information when communicating with people. With the development of mobile networks and the Internet, these objects have become easier to communicate with, and people have the opportunity to observe and control them from anywhere, anytime. (https://www.karel.com.tr/blog/internet-things-nesnelerin-interneti-nedircihazlarin-etkilesim-trend in)

\section{Internet of Services}

It is called the Internet of Services, which enables organizations and individuals to bring together new value-added services, facilitating access to services by supporting them with Internet technologies, such as the Internet of Things. In the Internet of Services, services and functions are represented as components of sensitive software and are offered by providers over the Internet (cloud). On the Internet of Services, cloud-based development and service platforms from various market players provide the option of simply developing and delivering web-compatible services (Özsoylu, 2017). The Internet of Services is recognized as one of the greatest potential growth areas for the Internet of the future. In particular, business-related services will be provided using the Internet and will be largely realized. While Web 2.0 applications such as Facebook and Twitter mainly target consumers / individuals, the Internet 
of Things and Services primarily targets companies and public administration. Internet search engines have made it possible to find information over the past decade. Semantic technologies will now find suitable services. This includes, among other things, a new Internet standard known as USDL (Unified Service Description Language) that allows services to be identified (https://www.seweurodrive.com/company/baarnz/future_trenders/industry_40/basic_information/basic_information). html).

\section{Smart Factories}

Smart factory, one of the main components of Industry 4.0, is not only connected to all production resources (sensors, actuators, machines, robots, conveyors, etc.) and automatically exchanging information; it is also a conscious and intelligent system that includes a digital integration that predicts and prevents machine failures, manages and controls the production process (Qin et al., 2016). Automation processes in smart factories mean that devices and machines communicate with each other to determine and regulate their production processes. For example, in the event of a shortage of resources at any stage of production, the required welding order is automatically placed, the failures occurring are detected immediately and remedied and the system can be run smoothly at full capacity (Siemens, 2017).

The most important factor that triggers the emergence of smart factories can be considered as a disruption of production activities in companies caused by human or tool errors. As a result of this situation, the development process of the Smart Factory concept, which enables the automation systems to proceed to the next stage, has begun to eliminate the existing problem. In this type of factory, which has some examples in our country, it is logical that all the tools, equipment and even the products produced are in communication with the revealed system. This communication is carried out with various software, sensor and robot technologies in the factory (Soylu, 2018).

Another important reason for the installation of smart factory systems is that it can be monitored 24/7. It is always possible to get instant and accurate data. As Prenote, we attach great importance to the fact that these data are understandable, and the system is easy to use. (https://proente.com/akilli-fabrika-nedir\%e $2 \% 80 \% 8 \mathrm{~b} /$ ).

Ongoing transformation utilizes various technologies to ensure the convergence of Information Technology and Operational Technology. The aim is to create intelligent systems that are connected, decentralized and self-optimizing. Some of the key technologies that support the Fourth Industrial Revolution are (https://www.cleverism.com/industry-4-0/\&prev=search):

\section{Autonomous Robots, Tools and Machines}

Robots, tools and machines learn from their interaction with humans and other machines. They use this knowledge base to perform more complex operations with increased autonomy.

\section{Simulation}

Simulations that use real-time data to reflect the physical world can be used to test and validate different scenarios in a virtual model.

\section{Horizontal and Vertical Integration}

An enterprise with an Industry 4.0 theme performs connectivity in different ways. Firstly; All physical assets, organizational units and employees within the enterprise are connected to each other via local network and Internet. Thus, the business is promoted to the level of doing business as a whole. This is called vertical integration. At the same time, the enterprise is responsible for the designers in its ecosystem, R \& D organizations, developers, suppliers, test centers, customers and so on. stakeholders. This is called horizontal integration. Both vertical and horizontal integration interfaces are developed to be compatible with each other - due to common standards and protocols.

Due to the horizontal integration, the services, systems and devices and employees of an enterprise can be accessed by other stakeholders, provided that they are authorized. The services produced by the enterprise over the network can be provided to internal and external customers or stakeholders without the problems that physical boundaries may create. The use of cyber-physical systembased infrastructure may be provided to service recipients authorized as a network service using components in Table 1.

Table 1: Cyber-physical system based infrastructure Components

Cyber security: As industrial systems are increasingly digitally connected, they will need an ever-higher level of protection against cyber threats. Therefore, the need for cyber security will be inevitable.

Additive production: Additional manufacturing methods are used to produce small quantities of customized products and offer construction advantages for complex designs.

Augmented reality: Augmented reality-based systems provide employees with real-time information to improve decision-making, simplify business procedures and improve security.

These concepts and technologies are evolving in response to customer demands. While meeting these demands is the greatest benefit of Industry 4.0, there are other cascading benefits for the entire supply chain in Table 2 : 
Table 2: Benefits of Industry 4.0 for a suppy-based activity in digital age

Increased productivity with automation: Automation reduces errors and delays, speeds up production and reduces waste. Increases the reliability of output that benefits the immediate neighbours in the supply chain.

Optimization in the digital supply chain: By linking cyber-physical systems and sharing information, optimization can be carried out among many entities in the supply chain and optimization can be increased from local to global. Optimization enables the best possible combination of operations, tools and parameter settings for the given conditions and constraints.

Real-time data for forecasting and optimization: Data analysis is used to predict machine and system behavior. This enables prevention and / or preparation for critical events that enable organizations to work more efficiently.

Data and analytics for optimization: Currently, the optimal use of resources and materials is achieved through offline planning. The plan was sub-optimized due to changes in real-world conditions during execution. With real-time data and analytics, the plan can be optimized for virtually real-time conditions.

Safer working and sustainable working environment: Real-time monitoring of operating conditions provides forecasting, rapid detection and enhanced protection. Remote operational control provides improved ergonomics and a safer working environment.

After entering the world of Industry 4.0, it will be insufficient to have the benefits only in production and engineering-related departments. The investment in the fourth industrial revolution should make itself felt in all areas. Particular attention should be paid to the point of marketing.

With Industry 4.0, it is thought that the value of the products and services offered by the enterprises will be increased and the quality will increase. In this way, it is assumed that the market will be reached more quickly and that it will be able to lead the market. The rapid and error-free production of products and services with the technologies offered by Industry 4.0 is of paramount importance, but at least as important is the fact that this is well reflected in marketing. Failure to carry out marketing with the performance required by digital marketing may reduce the value of products and services.

\section{Conclusion}

Today, with Industry 4.0, there is a major change in the world. The Internet has become an indispensable part of organizational processes. This significant change has affected every aspect of life. In these days when competition has reached unimaginable levels, advances in technology and globalization have increased the competitiveness of enterprises. Industry 4.0, the digital industrial revolution; it unites digital technology and industry in common ground. Robots that autonomously communicate with each other, detect the environment through sensors, and produce data by analysis are minimized the error rate in production. In addition, thanks to three-dimensional printers with Industry 4.0, cheap, high-quality production is provided. In this period, the demands of consumers are constantly changing. The desire to constantly search for the better and the new predominates. When this is the case, manufacturers have to keep their marketing perspectives up-to-date in order to cope with this. It is inevitable for them to develop organizational structures in this direction. Businesses can easily meet the expectations of their customers by using the benefits of the digital age while developing their products. Future seems to be with internet and digital technologies.

\section{References}

Acar, O. K. (2018). Entelektüel Sermaye Birikiminde İnsan Kaynaklari Yönetimi Politikalari: Süleyman Demirel Üniversitesi Örneği. Avrasya Uluslararası Araştırmalar Dergisi, 6(14), 193-215. DOI: 10.33692/avrasyad.510626

Alçın, S. (2016), Üretim İçin Yeni Bir İzlek: Sanayi 4.0, Journal of Life Economics, (8), pp. 19-30

Bilgiç, E and Esen, M. F. (2018) Endüstri 4.0 Işığında Veri Madenciliği Ve Pazarlama: Literatür Taramasıyla Son Gelişmeler, Yeni Trendler, Işletme Ekonomi ve Yönetim Araştırmaları Dergisi, (2) 21-29

Ertuğrul, İ and Deniz, G. (2018). 4.0 Dünyası: Pazarlama 4.0 ve Endüstri 4.0. Bitlis Eren Üniversitesi Sosyal Bilimler Enstitüsü Dergisi,7(1),158-170.

Frederick, D. (2016), libraries, Data and The Fourth Industrial Revolution, Library Hi Tech News, 33(5),9-12.

Gilgeous, V. and M Gilgeous (1999), Integrated Manufacturing Systems, 1999- emeraldinsight.com.

Gümüşoğlu, Ş. (2018). Bilimsel Yaklaşımlarla Değişim, Dönüşüm ve Kalite 4.0. Dokuz Eylül Üniversitesi İktisadi ve İdari Bilimler Fakültesi Dergisi,33(2),543-568.

Hacioglu, U., \& Sevgilioglu, G. (2019). The evolving role of automated systems and its cyber-security issue for global business operations in Industry 4.0. International Journal of Business Ecosystem \& Strategy (2687-2293), 1(1), 01-11. https://doi.org/10.36096/ijbes.v1i1.105 
Hacioglu, U. (2019). Blockchain Economics and Financial Market Innovation. Springer International Publishing, ISBN: 978-3-03025274-8

Hacioglu, U. (2020). Digital Business Strategies in Blockchain Ecosystems. Springer International Publishing, DOI: 10.1007/978-3030-29739-8

Hacioglu, U. (2020b). Handbook of Research on Strategic Fit and Design in Business Ecosystems (pp. 1-775). Hershey, PA: IGI Global. doi:10.4018/978-1-7998-1125-1

Jara, A. J., Parra, M. C., \& Skarmeta, A. F. (2012). Marketing 4.0: A new value added to the Marketing through the Internet of Things. 2012 Sixth International Conference on Innovative Mobile and Internet Services in Ubiquitous Computing, (p. 852857). Sanpaolo Palace Hotel, Palermo, Italy.

Kaban Kadığlu, Z. (2019). Uluslararası İletişim Düzeninde İnternet Tabanlı Küresel İletişim Şirketlerinin Rekabet Ortamları, Büyüme Stratejileri ve Toplumsal Dışsallıkları: Microsoft, Apple, Google ve Facebook. Erciyes İletişim Dergisi Uluslararası Dijital Çağda İletişim Sempozyumu Özel Sayısı, (1), 225-244. DOI: 10.17680/ erciyesiletisim.484684

Kılıç, S ve Alkan, M. (2018). Dördüncü Sanayi Devrimi Endüstri 4.0: Dünya ve Türkiye Değerlemeleri. Girişimcilik Inovasyon ve Pazarlama Araştırmacıları Dergisi, 2(3), 29-49.

Krauss, M. (2017). Marketing 4.0 Argues the Marketplace Has Changed, and the Customer is in Control. Marketing News, April/May, 26-27.

Ovacı, C. (2017). Endüstri 4.0 Çağında Açık İnovasyon. Maliye Finans Yazıları, Özel Sayı, 113-132.

Özsoylu, A. F. (2017). Endüstri 4.0. Çukurova Üniversitesi İ̈BF Dergisi, 21(1), 41-64.

Öztemel, E. ve Gürsev S. (2018). Türkiye'de Lojistik Yönetiminde Endüstri 4.0 Etkileri ve Yatırım İmkanlarına Bakış Üzerine Anket Uygulamas1. Marmara Fen Bilimleri Dergisi, 2, 145-154.DOI: 10.7240/marufbd.408560

Pamuk, N., S. ve Soysal, M.(?). Yeni Sanayi Devrimi Endüstri 4.0 Üzerine Bir İnceleme, Hacettepe Üniversitesi, İktisadi ve İdari Bilimler Fakültesi,İşletme Bölümü,Ankara. ( a thesis)

Sedefçi, K.(2018). Endüstri 4.0 Bakış Açısıyla Nesnelerin İnterneti Ve Müşteri Deneyimi Açısından İncelenmesi. Marmara Üniversitesi Sosyal Bilimler Enstitüsü İşletme Anabilim Dalı Global Pazarlama Bilim Dalı, İstanbul.(a thesis)

Sener, S. and Elevli, B. (2017). Endüstri 4.0'da Yeni İş Kolları ve Yüksek Öğrenim,Mühendis Beyinler Dergisi, 2(1), $2528-9802$.

Sert, S. (2008), Uluslararası Pazarlara Giriş Stratejileri Ve Bu Süreçte Ortaya Çıkabilecek Problemler: Uşak İli Tekstil Sektöründe Bir Araştırma, Afyon Kocatepe Üniversitesi, Sosyal Bilimler Enstitüsü İşletme Anabilim Dalı, Afyon. (A thesis)

Siemens. (2017). Endüstri 4.0 yolunda el kitapçı̆̆ı.

Soylu, A. (2018). Endüstri 4.0 ve Girişimcilikte Yeni Yaklaşımlar, Pamukkale Üniversitesi Sosyal Bililmler Enstitüsü Dergisi, sayı 32, Denizli, s.43-57.

Taş, H. Y. (2018). Dördüncü Sanayi Devrimi’nin (Endüstri 4.0) Çalışma Hayatına ve İstihdama Muhtemel Etkileri. OPUSUluslararası Toplum Araştırmaları Dergisi, 9(16), 1817-1836. DOI: 10.26466/opus.479123

Toker, K. (2018). Endüstri 4.0 ve Sürdürülebilirliğe Etkileri. Istanbul Management Journal, 29(84), 51-64.

Uslu, B., Gür, C. ve Eren, T.(2019). Endüstri 4.0 Uygulaması İçin Stratejilerin Aas ve Topsıs Yöntemleri İle Değerlendirilmesi. Eskişehir Teknik Üniversitesi Bilim ve Teknoloji Dergisi, 7(1), 13 - 28, DOI: 10.20290/aubtdb.440473

Ünlü, F., Atik, H. (2018). Türkiye'deki İşletmelerin Endüstri 4.0'a Geçiş Performansı: Avrupa Birliği Ülkeleri İle Karşılaştırmalı Ampirik Analiz. Ankara Avrupa Çalışmaları Dergisi, 17(2),431-463.

Yıldız A. (2018), Endüstri 4.0 İle Bütünleştirilmiş Dijital Tedarik Zinciri, BMIJ, (2018), 6(4): 1215-1230 doi:http://dx.doi.org/10.15295/bmij.v6i4.322

Yüksekbilgili, Z and Çevik., Z. G. (2018). Endüstri 4.0 Bağlamında Türkiye’nin Yerine İlişkin Güncel ve Gelecek Eksenli Bir Analiz. Nişantaşı Üniversitesi, Sosyal Bilimler Enstitüsü İşletme Yönetimi Bölümü, İstanbul. (a thesis).

\section{Internet sources}

http://blog.milliyet.com.tr/4-sanayi-devrimi--2---nesnelerin-interneti--siber-fiziksel-siztemler--akillifabrikalar/Blog/?BlogNo=541046, (ACCESS DATE: 20.06.2019)

https://ceylanparlakay.com/2017/03/27/pazarlama-ve-reklam-dunyasinda-endustri-4-0-bizi-nasil-etkiliyor/, (ACCESS DATE: 29.06.2019)

https://www.cleverism.com/industry-4-0/\&prev=search, (ACCESS DATE: 24.06.2019)

https://www.optessa.com/blog/industry-4-0-history-technology-business transformation/(https://www.fortuneturkey.com/akilliuretim-cagi-endustri-40-42841, (ACCESS DATE: 20.06.2019)

https://www.sanayidegelecek.com/en/sanayi-4-0/tarihsel-gelisim/, (ACCESS DATE: 18.06.2019) 
Appendix: A Literature Table on Industry 4.0

\begin{tabular}{|c|c|c|c|}
\hline Author (Date) & Subject & Components & Major Contributions \\
\hline $\begin{array}{l}\text { Ertuğrul and } \\
\text { Deniz,2018 }\end{array}$ & $\begin{array}{l}\text { World of } 4.0 \text { : Marketing } 4.0 \text { and } \\
\text { Industry } 4.0\end{array}$ & $\begin{array}{l}\text { Technology, Marketing } 4.0 \text {, } \\
\text { Industry } 4.0\end{array}$ & $\begin{array}{l}\text { Industry } 4.0 \text {; it is a joint whole of digital technology and } \\
\text { industry; It represents the fourth industrial revolution in } \\
\text { manufacturing and industry. }\end{array}$ \\
\hline $\begin{array}{l}\text { Kılıç and } \\
\text { Alkan, } 2018\end{array}$ & $\begin{array}{l}\text { Fourth Industry Industrial } \\
\text { Revolution 4.0: Valuation of the } \\
\text { World and Turkey. }\end{array}$ & $\begin{array}{l}\text { Industry } 4.0, \quad \mathrm{R} \& \mathrm{D} \\
\text { Investments, Industrial Robot, } \\
\text { Robot Density, Technology } \\
\text { Intensive Product }\end{array}$ & $\begin{array}{l}\text { Industry } 4.0 \text { brought to mind first the robots and employment } \\
\text { problems before they entered our country and its market. }\end{array}$ \\
\hline Taş, 2018 & $\begin{array}{l}\text { Possible Effects of the Fourth } \\
\text { Industrial Revolution (Industry } 4.0 \text { ) } \\
\text { on Work Life and Employment. }\end{array}$ & $\begin{array}{l}\text { Industry 4.0, Employment, } \\
\text { Innovation, Technology, 4th } \\
\text { Industrial Revolution }\end{array}$ & $\begin{array}{l}\text { Industry } 4.0 \text { brought to mind first the robots and employment } \\
\text { problems before they entered our country and its market }\end{array}$ \\
\hline $\begin{array}{l}\text { Yüksekbilgili } \\
\text { and Çevik, } \\
2018\end{array}$ & $\begin{array}{l}\text { In the context of Industry } 4.0 . \\
\text { Current and Future Analysis Axis } \\
\text { regarding Turkey's place. }\end{array}$ & $\begin{array}{l}\text { Industry, industry, competition, } \\
\text { economy, revolution, } \\
\text { marketing. }\end{array}$ & $\begin{array}{l}\text { With the introduction of Industry } 4.0 \text {, intelligent robots will } \\
\text { be on the production lines, so that while the error rate } \\
\text { decreases, the enterprises will be progressing with great steps } \\
\text { in terms of efficiency and quality. }\end{array}$ \\
\hline $\begin{array}{l}\text { Uslu, Gür and } \\
\text { Eren, } 2019\end{array}$ & $\begin{array}{l}\text { Evaluation of Strategies for } \\
\text { Industry 4.0 Application with AAS } \\
\text { and Topsis Methods }\end{array}$ & $\begin{array}{l}\text { Industry } 4.0, \text { Multi-criteria } \\
\text { decision making, Analytical } \\
\text { network process, TOPSIS }\end{array}$ & $\begin{array}{l}\text { In this study, the concept of Industry } 4.0 \text { is mentioned. For } \\
\text { Industry } 4.0 \text {, which strategies companies can focus on are } \\
\text { listed and ten key criteria for these strategies have been } \\
\text { identified. }\end{array}$ \\
\hline Toker, 2018 & $\begin{array}{l}\text { Industry } 4.0 \text { and Its Impact on } \\
\text { Sustainability }\end{array}$ & $\begin{array}{l}\text { Industrial Revolution, Industry } \\
4.0 \text {, Sustainability }\end{array}$ & $\begin{array}{l}\text { It is expressed that Industry } 4.0 \text { will use less fossil fuel in its } \\
\text { production processes, bio-energy and sustainable energy } \\
\text { sources will gain importance and governments will make } \\
\text { arrangements to encourage investments in this direction. }\end{array}$ \\
\hline Özsoylu, (2017) & Industry 4.0 & $\begin{array}{l}\text { Intelligent production, Cloud } \\
\text { computing, Internet of things, } \\
\text { Big data, Cyber physical } \\
\text { systems }\end{array}$ & $\begin{array}{l}\text { Accepted as the fourth stage of industrialization, Industry } 4.0 \\
\text { is a new process that will affect all layers of society as well } \\
\text { as the private and public sectors. The IT infrastructure that } \\
\text { constitutes Industry } 4.0 \text { realizes intelligent production, new } \\
\text { business models emerge with intelligent production and as a } \\
\text { result radical changes are expected in the processes ranging } \\
\text { from daily life to working life, from the structure of products } \\
\text { to the supply and sale. }\end{array}$ \\
\hline $\begin{array}{l}\text { Kaban and } \\
\text { Kadıoğlu, } \\
(2019)\end{array}$ & $\begin{array}{l}\text { In International Communication } \\
\text { System Competitive Environments } \\
\text { of Internet Based Global } \\
\text { Communication Companies, Their } \\
\text { Growth Strategies and Social } \\
\text { Externalities: Microsoft, Apple, } \\
\text { Google and Facebook }\end{array}$ & $\begin{array}{l}\text { Global Communications } \\
\text { Companies, Purchasing in } \\
\text { Technology Companies, } \\
\text { Competition in Digital } \\
\text { Communications Industry, } \\
\text { Google, Facebook, Microsoft, } \\
\text { Apple. }\end{array}$ & $\begin{array}{l}\text { The dominant forces of the international communication } \\
\text { system today are technology-based internet companies. Both } \\
\text { their domains, their databases and the power of their } \\
\text { economic magnitude have made them dominant. }\end{array}$ \\
\hline $\begin{array}{l}\text { Büyükkalaycı } \\
\text { and Karaca, } \\
(2019)\end{array}$ & Marketing 4.0: Internet of Things & $\begin{array}{l}\text { Marketing Stages, Marketing } \\
4.0, \quad \text { Digital Marketing, } \\
\text { Customer Interaction, Internet } \\
\text { of Things }\end{array}$ & $\begin{array}{l}\text { Marketing } 4.0 \text { and the Internet of objects are explained in } \\
\text { detail and the relationship between them is examined. As a } \\
\text { result, it is foreseen that the Internet of Things is an important } \\
\text { issue, and in Marketing } 4.0 \text {, it's foreseen that companies } \\
\text { should be among the indispensable technologies that they } \\
\text { need to provide competitive advantage, hold existing } \\
\text { customers and gain potential customers or use them to be } \\
\text { superior to their competitors. }\end{array}$ \\
\hline Sert, (2008) & $\begin{array}{l}\text { Strategies of Entering to the } \\
\text { International Markets and Possible } \\
\text { Problems of this process: Uşak } \\
\text { Province,A Research in Textile } \\
\text { Sector }\end{array}$ & & $\begin{array}{l}\text { The textile sector which is the locomotive of the Turkey's } \\
\text { economy should be noticed necessarily. The aim is achieving } \\
\text { development as a whole industry. The necessary support } \\
\text { should be provided to make companies give importance to } \\
\text { their research and development activities. }\end{array}$ \\
\hline $\begin{array}{l}\text { Doğru and } \\
\text { Mecik (2018) }\end{array}$ & $\begin{array}{l}\text { Industry } 4.0 \text { Impact on the Labor } \\
\text { Market in Turkey: Business } \\
\text { Expectations }\end{array}$ & $\begin{array}{l}\text { Industry 4.0, Labor Market, } \\
\text { Employment, Company } \\
\text { Expectations, Turkey }\end{array}$ & $\begin{array}{l}\text { It is understood that the Fourth Industrial Revolution is a } \\
\text { long-term process that requires many structural analyzes. } \\
\text { Turkey, as a country that attracts the difficulties being } \\
\text { adapted to technological progress, as well as the private } \\
\text { sector should continue its efforts to capture new industrial } \\
\text { revolution that unless steps in recent years with the support } \\
\text { of the public sector, where it is observed. }\end{array}$ \\
\hline $\begin{array}{l}\text { Pamuk } \\
\text { Soyal }\end{array}$ & $\begin{array}{l}\text { A Review of the New Industrial } \\
\text { Revolution Industry } 4.0\end{array}$ & $\begin{array}{l}\text { Production Management, } \\
\text { Industrial Revolution, Industry } \\
4.0 .\end{array}$ & $\begin{array}{l}\text { According to the information obtained from the research, the } \\
\text { use of the Industry } 4.0 \text { concept is increasing in both the } \\
\text { business world and the literature. The Internet of things, the } \\
\text { cyber-physical system, big data and data analytics, and smart } \\
\text { factories are the main sources used as intermediaries to } \\
\text { achieve the Fourth Industrial Revolution. }\end{array}$ \\
\hline
\end{tabular}


Soylu, (2018)

Industry 4.0 and New Approaches in Entrepreneurship
Industry 4.0, Entrepreneurship, New Business Models

$\begin{array}{llll}\text { Sener and } & \text { New Businesses and Higher } & \text { Industry 4.0, 4. Industrial } \\ \text { Elevli, (2017) } & \text { Education in Industry } 4.0 & & \text { Revolution, Digitalization }\end{array}$

Bilgiç and Esen Data Mining and Marketing in the (2018) Light of Industry 4.0: Recent Developments with Literature Review, New Trends

\section{Industry 4.0, Marketing, Data}

Mining, Text Mining, Machinery Learning

Looking at developments that are predicted to have a profound impact on business in the near future, human body implantable technologies, vision technologies, wearable internet, advanced mobile communication technologies, smart homes and cities, internet of objects, artificial intelligence and robotics technologies, Blockchain applications, 3D printers and sharing economy stand out as emerging issues. Initiatives in this area are likely to achieve great gains.

Instead of renewing the existing education system and waiting for the adaptation process, an alternative that can be acted faster should be created. Already in the projections, it is not foreseen that individuals related to Industry 4.0 will be specialized in a single subject. Instead, generations are required that are more easily adaptable to emerging technologies and can use them immediately.

Industry 4.0, Marketing, Data Mining, Text Mining,

Machinery Learning In parallel with e-commerce shopping

volume development in recent years, despite the increase in e-commerce related studies and considering the fact that the majority of customers are currently shopping from real stores (bricks and mortar), there has been an increase in studies related to in-store applications in recent years.

\begin{tabular}{lllllr}
\hline Ünlü and Atik & Industry & 4.0 & Transition & Industry 4.0, Factor Analysis, \\
(2018) & Performance of Enterprises in & Cluster Analysis, Europe \\
& Turkey: European Union Countries & Union, Turkey & \\
& with Comparative Empirical & & \\
& Analysis & & &
\end{tabular}

\begin{tabular}{lllll}
\hline Gümüşoğlu & Change & with Scientific & Quality 4.0, World Class \\
(2018) & Approaches, Transformation and & Manufacturing, Industry 4.0, \\
& Quality 4.0 & & ERP II, Technology, Crypto \\
& & Money, Digital Domestic, \\
& & Modern Quality Function \\
& & Deployment, Quality Culture
\end{tabular}

In the globalization process, which has become inevitable with the spread of information and communication technologies, production of goods and services in line with the changing demand structure has gained importance. The production of products suitable for new production and consumption patterns in the world will be possible thanks to the conversion to Industry 4.0.

Quality 4.0 is an excellent strategy used to adapt the traditional work to the new system, supporting the Industry 4.0 goal and matching quality with the corporate structure. Most manufacturers in organizations have goals such as efficiency, efficiency, cost, performance, and information technology, big data, mobile applications, compliance, partnerships, etc. within the framework of human, technology management systems. carry out their work intertwined with the components.

\begin{tabular}{lll}
\hline Sedefçi (2018) & $\begin{array}{l}\text { Investigation of Objects from the } \\
\text { Perspective of Industry } 4.0 \text { and }\end{array}$ \\
& $\begin{array}{l}\text { Internet and Customer Experience } \\
\text { Boomers-X-Y-Z Internet of Things, }\end{array}$ \\
&
\end{tabular}

result; At this point, Industry 4.0 has opened the doors to a new industrial world. This process is shaping the future by making the most important technological and digital inventions of today, especially the internet, based on itself.

\begin{tabular}{|c|c|c|c|}
\hline $\begin{array}{l}\text { Öztemel and } \\
\text { Gürsev (2018) }\end{array}$ & $\begin{array}{l}\text { In Logistics Management, Industry } \\
4.0 \text { Impact in Turkey and Survey on } \\
\text { the view of Investment Facilities }\end{array}$ & $\begin{array}{l}\text { Industry } 4.0, \text { Logistics } 4.0 \text {, } \\
\text { Innovation, Strategic Logistics } \\
\text { Management }\end{array}$ & $\begin{array}{l}\text { It has been determined that Industry } 4.0 \text { approach is not } \\
\text { perceived correctly and some technological components } \\
\text { cause negative opinions. The fact that mostly small and } \\
\text { medium sized companies take place in the sector revealed the } \\
\text { importance of the investment plans for the industry } 4.0 \\
\text { journeys to the firms. }\end{array}$ \\
\hline Yıldız (2018) & $\begin{array}{l}\text { Digital Supply Chain Integrated } \\
\text { with Industry } 4.0\end{array}$ & $\begin{array}{l}\text { Industry } 4.0 \text {; Digital Supply } \\
\text { Chain; Internet of Things; } \\
\text { Cloud computing }\end{array}$ & $\begin{array}{l}\text { With the introduction of the Industry } 4.0 \text { revolution, the } \\
\text { methods like } 3 \mathrm{D} \text { printer, augmented reality, internet of } \\
\text { objects, cyber physical systems, artificial intelligence, big } \\
\text { data, simulation, etc it is aimed to establish smart factories } \\
\text { that can think and make decisions by itself via methods, to } \\
\text { create smart supply chains and to produce and distribute } \\
\text { smart products in this way. }\end{array}$ \\
\hline
\end{tabular}

